\title{
Cucullanus marajoara n. sp. (Nematoda: Cucullanidae), a parasite of Colomesus psittacus (Osteichthyes: Tetraodontiformes) in the Marajó, Brazil
}

\author{
Cucullanus marajoara n. sp. (Nematoda: Cucullanidae), um parasito de Colomesus psittacus
} (Osteichthyes: Tetraodontiformes) no Marajó, Brasil

Raul Henrique da Silva Pinheiro ${ }^{1,2}$; Ricardo Luis Sousa Santana ${ }^{2}$; Scott Monks ${ }^{3}$; Jeannie Nascimento dos Santos ${ }^{1,4}$; Elane Guerreiro Giese ${ }^{1,2^{*}}$

\begin{abstract}
${ }^{1}$ Programa de Pós-graduação em Biologia de Agentes Infecciosos e Parasitários, Instituto de Ciências Biológicas, Universidade Federal do Pará - UFPA, Belém, PA, Brasil

${ }^{2}$ Laboratório de Histologia e Embriologia Animal, Instituto da Saúde e Produçăo Animal, Universidade Federal Rural da Amazônia UFRA, Belém, PA, Brasil

${ }^{3}$ Laboratorio de Morfología Animal, Centro de Investigaciones Biológicas, Universidad Autónoma del Estado de Hidalgo Pachuca, Pachuca, Hidalgo State, México

${ }^{4}$ Laboratório de Biologia Celular e Helmintologia Profa Dra Reinalda Marisa Lanfredi, Instituto de Ciências Biológicas, Universidade Federal do Pará - UFPA, Belém, PA, Brasil
\end{abstract}

Received June 29, 2018

Accepted August 22, 2018

\begin{abstract}
Cucullanus marajoara n. sp. (Cucullanidae) is reported to parasitize Colomesus psittacus (Tetraodontiformes), which is a fish species from the Marajó Archipelago, state of Pará, estuarine region of the Brazilian Amazon. The new species differs from similar species by the presence of a protruding upper lip on the cloacal opening, the distribution of the cloacal papillae: five pre-cloacal papillae pairs and 5 are ventral and located posteriorly to the pre-cloacal sucker and an unpaired papilla is located on the upper cloacal lip and five post-cloacal pairs, and a pair of lateral phasmids located between papillae pairs. Additionally, Cucullanus marajoara n. sp. is compared to other species of this genus described in Brazil, particularly Cucullanus ageneiosus and Cucullanus oswaldocruzi, which both occur in the same zoogeographic region of this study but parasitize fish of a different order (Siluriformes). Cucullanus dodsworthi and Cucullanus brevicaudatus are the only described species parasitizing fish of the order Tetradontiformes in Brazil, and the new species differs from these species by the distribution of the cloacal papillae and the host habitat. The description of Cucullanus marajoara $\mathrm{n}$. sp. adds data to the biodiversity of described parasites that parasitize Tetradontiformes of the estuarine ichthyofauna in the Brazilian Amazon.
\end{abstract}

Keywords: Helminth, parasite, nematoda, puffer fish.

\section{Resumo}

Cucullanus marajoara n. sp. (Cucullanidae) é descrita parasitando Colomesus psittacus (Tetraodontiformes) peixe do arquipélago de Marajó, Estado do Pará, região estuarina da Amazônia brasileira. A nova espécie difere de seus congêneres por apresentar lábio superior da abertura cloacal protrudente e na distribuiçáo de papilas cloacais: 5 pares pré-cloacais, e uma papila não pareada no lábio superior da cloaca e 5 pares pós-cloacais, um par de fasmídeos laterais. Além disso, Cucullanus marajoara n. sp. é comparada com outras espécies do gênero descritas no Brasil, em especial Cucullanus ageneiosus e Cucullanus oswaldocruzi, ambos parasitos de peixes da ordem Siluriformes; porém, ocorrendo na mesma região zoogeográfica deste estudo, diferem da ordem do hospedeiro da nova espécie (Tetraodontiformes). Cucullanus dodsworthi e Cucullanus brevicaudatus são as únicas espécies descritas parasitando peixe da ordem Tetradontiformes no Brasil, e a nova espécie difere dessas na distribuição das papilas cloacais e habitat dos hospedeiros. Cucullanus marajoara n. sp. adiciona dados a biodiversidade de parasitos descritos parasitando Tetradontiformes da ictiofauna estuarina da Amazônia brasileira.

Palavras-chaves: Helminto, parasito, nematoda, baiacu.

\footnotetext{
${ }^{*}$ Corresponding author: Elane Guerreiro Giese. Laboratório de

Histologia e Embriologia Animal, Instituto da Saúde e Produção Animal,

Universidade Federal Rural da Amazônia - UFRA, Avenida Presidente

Tancredo Neves, 2501, Terra Firme, CEP 66077-830, Belém, PA, Brasil.

e-mail: elane.giese@ufra.edu.br
} 


\section{Introduction}

The northern estuary of Brazil has a rich ichthyofauna, particularly fish of the order Tetraodontiformes. Among these, the family Tetraodontidae includes four species: Colomesus psittacus (Bloch \& Schneider, 1801), Colomesus asellus (Müller \& Troschel, 1849), Colomesus tocantinensis Amaral, Brito, Silva \& Carvalho (2013), Sphoeroides testudineus (Linnaeus, 1758), and Lagocephalus laevigatus (Linnaeus, 1766) (KRUMME et al., 2004). Colomesus psittacus, popularly known in Brazil as "baiacu" (puffer fish), is a demersal fish of marine-estuarine waters with depths of up to $40 \mathrm{~m}$, although it often is found in freshwater. This species is distributed in the Western Atlantic principally from the Gulf of Paria (Venezuela) in the north to the Amazon River, state of Pará in Brazil (CERVIGON et al., 1992; FROESE \& PAULY, 2018 ) in the south. Baiacu can be found throughout the entire Amazonian estuary (CAMARGO \& MAIA, 2008).

The genus Cucullanus Müller (1777), contains approximately 100 fish parasite species worldwide (TIMI \& LANFRANCHI, 2006; GIESE et al., 2010; LACERDA et al., 2015). Approximately 32 species have been described in the Neotropical region of the American continent (LÓPEZ-CABALLERO et al., 2009; GIESE et al., 2010; LACERDA et al., 2015). The species Cucullanus genypteri Sardella, Navone \& Timi, 1997, C. marplatensis Daniel, Timi \& Sardella, 2002, and C. bonaerensis Lanfranchi, Timi \& Sardella, 2004 were described in South America. Cucullanus pedroi was described in Argentina (TIMI \& LANFRANCHI, 2006). Cucullanus colossomi Díaz-Ungría, 1968, that is a parasite of Colossoma macropomum, was found in the Orinoco River, Venezuela, and Cucullanus bagre Petter, 1974, that is a parasite of Bagre bagre, was described in French Guiana.

For fish from Brazil, Luque et al. (2011) listed Cucullanus cirratus Müller, 1777, Cucullanus pulcherrimus Barreto, 1918; Cucullanus dodsworthi Barreto, 1922; Cucullanus pinnai Travasso, Artigas, \& Pereira, 1928; Cucullanus zungaro Vaz \& Pereira, 1934; Cucullanus pauliceae Vaz \& Pereira, 1934; Cucullanus schubarti Travasso, 1947; Cucullanus mogi Travassos, 1947; Cucullanus carioca Vicente \& Fernandes, 1973; C. rougetae Vicente \& Santos, 1974; Cucullanus oswaldocruzi Santo, Vicente \& Jardim, 1979; Cucullanus grandistomis (Ferraz \& Thatcher, 1988); Cucullanus patoi Fortes, Hoffmann \& Sarmento, 1992; Cucullanus brevispiculus Moravec, Konh \& Fernandes, 1993; Cucullanus pimelodellae Moravec, Kohn \& Fernandes, 1993; Cucullanus fabregasi Fortes, Hoffmann \& Sarmento, 1993; Cucullanus riograndensis Fortes, Hoffmann \& Sarmento, 1993; Cucullanus debacoi Sarmento, Fortes \& Hoffmann, 1995; Cucullanus cassinensis Pereira Jr. \& Costa, 1996; Cucullanus pinnai pterodorasi Moravec, Kohn \& Fernandes, 1997; Cucullanus pseudoplatystomae Moravec, Kohn \& Fernandes, 1997; Cucullanus rhamphichthydis Moravec, Kohn, and Fernades, 1997; Cucullanus heliomartinsi Moreira, Rocha \& Costa, 2000; and Cucullanus ageneiosus Giese, Furtado, Lanfredi \& Santos, 2010. Moravec (1998) considered C. patoi, C. fabregasi, C. riograndensis, and C. debacoi, and Timi et al. (2009) considered C. cassinensis to be species inquirenda.

Pereira et al. (2014) described Cucullanus brevicaudatus as a parasite of Balistes capriscus, a marine fish collected in Rio de Janeiro state, Brazil. Vieira et al. (2015) described Cucullanus gastrophysi, Cucullanus protrudens, and Cucullanus pseudopercis and redescribed Cucullanus cirratus, Cucullanus pedroi, and Cucullanus genypteri from fish collected from the same state and thus added new data to the biodiversity of Cucullanidae parasites from Brazilian fish fauna. Lacerda et al. (2015) described Cucullanus tucunarensis as a parasite of Cichla piquiti (Cichliformes) in the Tocantins River and Pereira \& Luque (2017) described Cucullanus opisthoporus in Cichla melaniae in the Xingu River, Pará.

Colomesus psittacus commonly enters the fish traps along the shore, but they are not harvested because they produce a tetradoxina toxic to humans (SANTANA et al., 2010). The fishermen discard the fish outside of the traps. Because they were available abundantly and not part of the local source of food, we decided to investigate the parasite fauna of the species. During this study, a new species of Cucullanus was found; it is described herein and compared with other members of the genus recorded from the same zoogeographical region and the same group of hosts (Tetraodontiformes).

\section{Materials and Methods}

Twenty specimens of $C$. psittacus were caught by fishermen

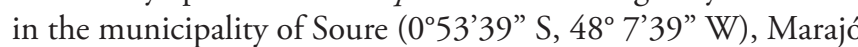
Archipelago, Pará state (Brazil). The fish were obtained from riverine fishermen who discarded them from their catch and were transported on ice to the Laboratório de Histologia e Embriologia Animal, Instituto da Saúde e Produçáo, Universidade Federal Rural da Amazônia, Campus Belém, Pará state, Brazil. The weight $(\mathrm{g})$ and total length $(\mathrm{cm})$ of the specimens were measured. After biometric analysis, the animals were necropsied to search for helminths. The digestive tract was isolated in petri dishes containing physiological solution and analyzed under a stereomicroscope (Leica - ES2). The collected helminths were fixed in an alcohol-formaldehyde-acetic acid (AFA) solution $(930 \mathrm{~mL}$ of $70 \%$ ethanol, $50 \mathrm{~mL}$ of commercial formalin, and $20 \mathrm{~mL}$ of glacial acetic acid) stored at room temperature. Subsequently, the specimens were dehydrated in an ethanol series, clarified with Aman's lactophenol, and examined by light field microscopy using a Leica DM2500 microscope with a clear camera for scientific imaging and morphometric analysis.

Ten male specimens and ten female specimens were used for the morphometric analysis of the helminths. The measurements were made in millimeters as the means, with the ranges shown in parentheses. For scanning electron microscopy, the helminth specimens were washed in distilled water, postfixed in $1 \%$ osmium tetroxide, dehydrated to the critical point of $\mathrm{CO}_{2}$, metallized with gold + palladium, and analyzed using a TESCAN scanning electron microscope (VEGA 3) in the Laboratório de Microscópia Eletrônica de Varredura da Universidade Federal Rural da Amazônia. There are more than 100 putative species in the genus, so the suggestions of (YOOYEN et al., 2011; LACERDA et al., 2015), that morphological and morphometric comparisons should be made only among the different species that parasitize the same taxonomic group of hosts from the same zoogeographical region in which the host was found. The host fishes scientific name is in accordance with FishBase (FROESE \& PAULY, 2018). 


\section{Results}

\section{Survey data}

Of the 20 specimens of $C$. psittacus collected in the Soure municipality, 90\% (18 infected fish/ 20 examined fish) were parasitized by nematodes of the genus Cucullanus, which we compared in their morphology and morphometric with other members of the genus recorded for the zoogeographic region and the same group of hosts, and we proposed the species Cucullanus marajoara n. sp.

Family Cucullanidae Cobbold 186

Cucullanus marajoara n. sp.

(Based on light microscopy and scanning electron microscopy examination: Figs. 1-3)

Medium-sized nematode, opaque white when alive. Females are larger than males, and the morphology of the anterior region is similar in both genders (Figures 1a and 2a). A thick cuticle forms a lateral cervical flap in some specimens, and the presence of thin transverse striae are observed along the body. The cephalic end is rounded, and an oral aperture in the form of a dorsoventral cleft is surrounded by a cuticular ring and delimited by a row of small teeth (Figures 2a-b). Presence of four external cephalic papillae, four internal papillae, and a pair of dorsolateral amphids (Figures 2a-b). The claviform muscular oesophagus is divided into two distinct and well-developed regions, and a well sclerotized anterior region forming an oral pseudocapsule (oesophastome) with a nerve ring is located in this region (Figure 1a). The posterior region of the oesophagus is expanded and opens into the intestine by a strong valve. The diverticulum of the oesophagus and intestinal cecum are absent. Deirids at level of the middle glandular oesophagus, and the excretory pore is located below the oesophagus (Figures 1a, 2c-d).

Males (Based on 10 specimens, measurements of the holotype in brackets): Body length of 7.59 (6.0-10.6) [8], and maximum width at the junction between the esophagus and bowel of $0.27(0.19-0.36)$ [0.29]. Muscular oesophagus with a size of $0.76(0.63-0.91)[0.77] \times 0.13(0.1-0.2)$ [0.13]. Oesophastome with a size of $0.28(0.25-0.33)[0.28] \times 0.14(0.13-0.16)$ [0.14]; the oesophagus represents $10 \%(8-13 \%)$ [10\%] of the total body length. The nerve ring, deirids, and excretory pore are positioned $0.32(0.22-0.86)$ [0.26], $0.65(0.52-0.76)$ [0.63], and $0.81(0.65-0.97)$ [0.78] from the cephalic end, respectively. A muscular precloacal sucker with a diameter of $0.10(0.08-0.15)$ [0.097] is located $0.76(0.61-0.88)$ [0.84] from the posterior extremity (Figures 1b, c, 3a). The cloacal opening has a protruded upper lip (Figures 1b, 3d). Postdeirids are not observed. Ten pairs of caudal papillae are observed as follows: five precloacal pairs (the first pair is located anteriorly to the cloacal sucker, and pairs No. 2, 3, 4, and 5 are ventral and located posteriorly to the cloacal sucker) and five postcloacal pairs (pairs No. 6, 8, and 10 are ventral, pair No. 7 is lateral, and pair No. 9 is dorsal); a pair of lateral phasmids is located between pairs No. 8 and 10 (Figures $1 \mathrm{~b}-\mathrm{c}$ and $3 \mathrm{a}-\mathrm{c}$ ). Unpaired ventral papilla is located slightly anterior to the cloacal protrusions (Figures $1 \mathrm{~b}-\mathrm{c}$ and $3 \mathrm{~d}$ ). The spicules are long, filiform, subequal, and sclerotized, with a length of 0.78 (0.56-1.00) [0.78], representing $10 \%(8-12.5 \%)$ [9.75\%] of the total body length (Figures 1b, c and 3a). The gubernaculum is sclerotized and is

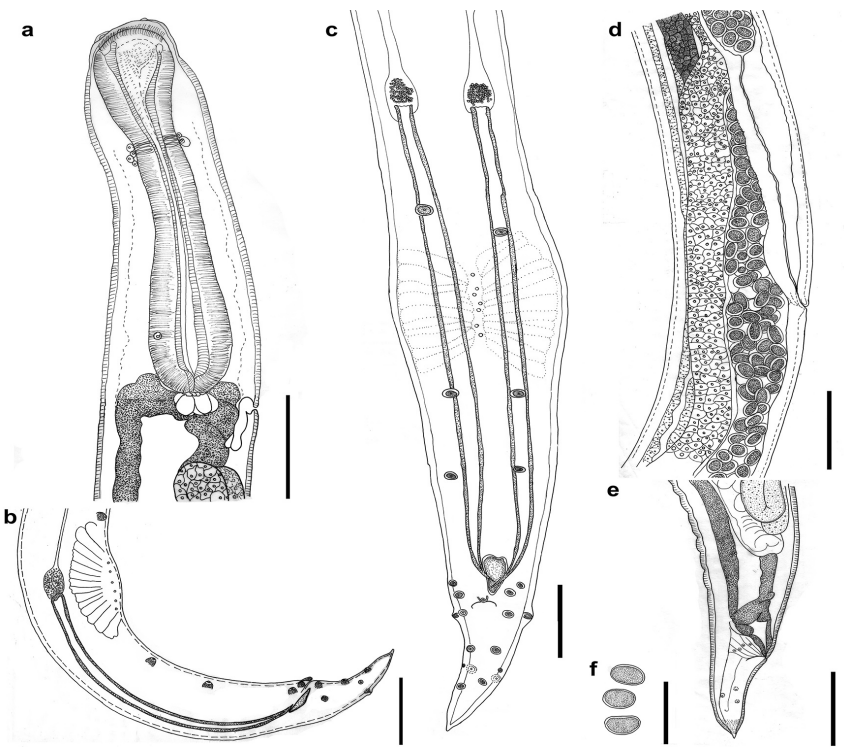

Figure 1. Cucullanus marajoara n. sp. a parasite of Colomesus psittacus from Soure, Marajó Archipelago, state of Pará, eastern Amazon, Brazil: (a) Cephalic region view. Bar $=100 \mu \mathrm{m}$; (b) Posterior end of male, lateral view. $\mathrm{Bar}=100 \mu \mathrm{m}$; (c) Caudal region of male, ventral view. $B a r=150 \mu \mathrm{m}$; (d) Vulval region, lateral view. $B a r=100 \mu \mathrm{m}$; (e) Egg from ovijector. Bar $=100 \mu \mathrm{m}$; (f) Posterior end of female, lateral view. $\mathrm{Bar}=200 \mu \mathrm{m}$.
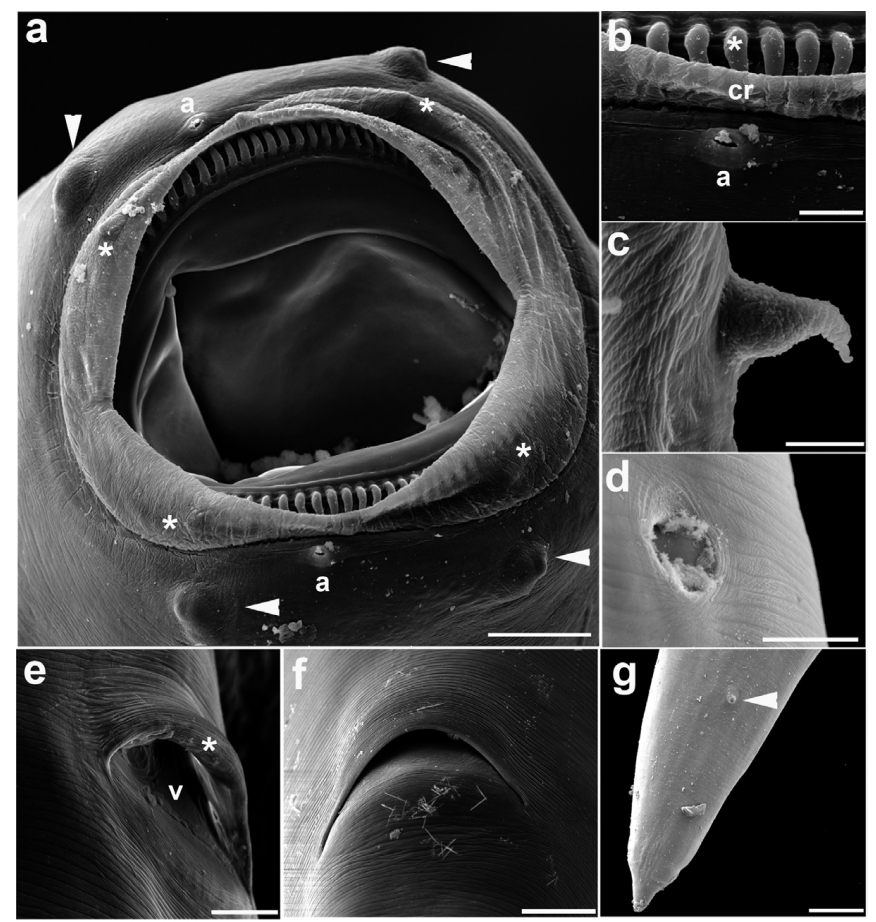

Figure 2. Cucullanus marajoara n. sp. of Colomesus psittacus. Scanning electron micrographs of a female: (a) Cephalic region subapical views, oral aperture with four external papillae (arrowheads), four internal papillae $\left(^{*}\right)$, and amphid (a). Bar $=20 \mu \mathrm{m}$; (b) Detail showing the oral aperture with teeth $\left(^{*}\right)$ surrounded by a cuticular ring (cr) and amphid (a). Bar $=5 \mu \mathrm{m}$; (c) Deirid. Bar $=5 \mu \mathrm{m}$; (d) Excretory pore (ep). Bar $=10 \mu \mathrm{m}$; (e) Vulval region (v) and protruding upper lip $\left({ }^{*}\right)$ in the lateral view. $\mathrm{Bar}=20 \mu \mathrm{m}$; (f) A anal region, ventral view. Bar $=20 \mu \mathrm{m}$; (g) Arrowheads indicate phasmids. Bar $=25 \mu \mathrm{m}$. 
spoon-shaped in the lateral view, with a length of 0.07 (0.06-0.08) [0.08]. The conical tail has a length of $0.22(0.20-0.26)$ [0.22]; the caudal alae and cuticular projection are absent (Figures 1c and 3a).

Females (Based on 10 gravid specimens with immature eggs, measurements of allotype in brackets): Body length of 9.5 (7.55-12.12) [12.12], maximum width at the junction between the esophagus and intestine of $0.35(0.28-0.46)$ [0.39]. The oesophastome has a size of $0.3(0.28-0.33)[0.33] \times 0.15(0.13-0.17)[0.17]$; the muscular oesophagus has a size of $0.84(0.76-0.91)[0.91] \times 0.15$ $(0.13-0.18)$ [0.18], with the oesophagus representing 9\% (7-11\%) [7.6] of the total body length. The nerve ring, deirids, and excretory pore are located $0.29(0.26-0.32)$ [0.3], $0.76(0.64-0.95)$ [0.91], and $0.95(0.78-1.23)$ [0.94] from the anterior extremity, respectively. Vulva postequatorial is located 5.96 (4.68-7.75) [7.75] from the cephalic end and has a prominent upper lip (Figures 1d and 2e). The eggs have a size of $0.04(0.03-0.05)$ $\times 0.03(0.03-0.04)$ (Figures 1d, f). Tail conical has a length of $0.26(0.23-0.31)[0.25]$; the phasmids are conspicuous and lack a cuticular projection at the extremity (Figures 1e, $2 \mathrm{~g}$ ). The anus has a prominent upper lip (Figures 1e, 2f).
Taxonomy Summary:

Cucullanus marajoara n. sp.

Host: Colomesus psittacus Bloch and Schneider, 1801 (Tetraodontiformes: Tetraodontidae) - Common name: Baiacu (puffer fish)

Average length and weight of hosts: $35.5 \mathrm{~cm}$ and $368.5 \mathrm{~g}$, respectively.

Site of infection: Middle intestine.

Biome: Amazon - Environment: Estuarine

Location type: Municipality of Soure, Marajó Archipelago, state of Pará, Brazil.

Prevalence: 90\% (20 host examined, 18 hosts infected)

Etymology: The specific name marajoara refers to the geographical region of the distribution (i.e., Arquipélago de Marajó, state of Pará, Amazon, Brazil).

Deposit of Specimens: Coleção Helmintológica do Instituto Oswaldo Cruz

(acronym CHIOC), State of Rio de Janeiro, Brazil: Cucullanus marajoara n. sp. CHIOC 38584 a-h (holotype: $38584 \mathrm{a}$
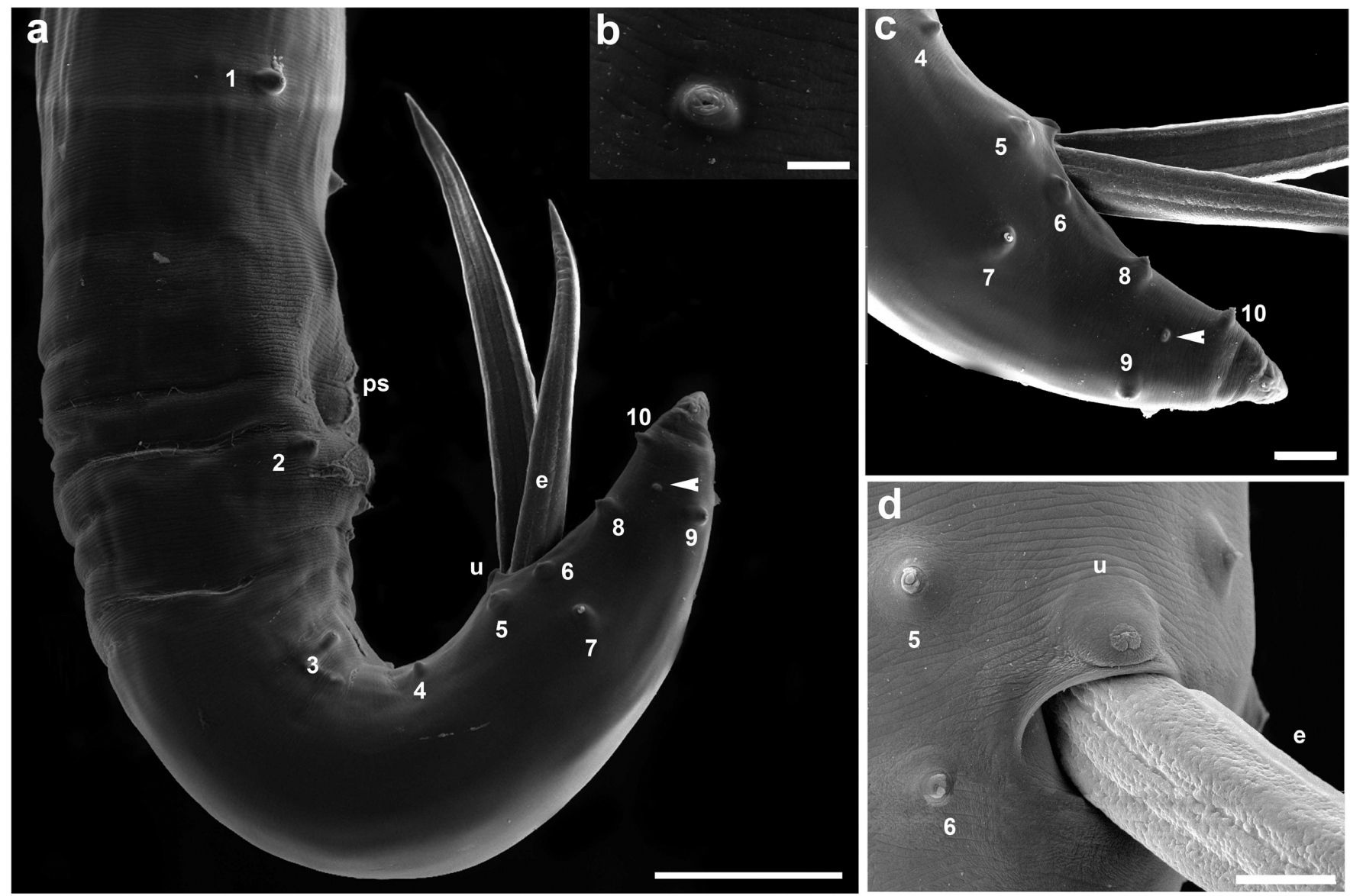

Figure 3. Cucullanus marajoara n. sp. of Colomesus psittacus. Scanning electron micrographs of a male: (a) Tail region, lateral view, caudal papillae, 10 pairs: five pre-cloacal pairs (the first pair is located anterior to the pre-cloacal sucker, whereas pairs No. 2, 3, 4, and 5 are ventral and located posterior to the pre-cloacal sucker) and five post-cloacal pairs (pairs No. 6, 8, and 10 are ventral, pair No. 7 is lateral, and pair No. 9 is dorsal); the pseudosucker (ps) and pair of lateral phasmids are located between pairs No. 8 and 10 and the spicule (e). Bar $=100 \mu$ m; (b) Detail of phasmids. Bar $=5 \mu \mathrm{m}$. (c) Detail of the tail showing four pairs of ventral papillae (No. 5, 6, 8, and 10), a lateral pair (No. 7), a dorsal pair (No. 9), and phasmids (arrowheads). Bar $=25 \mu \mathrm{m}$; (d) Detail of the unpaired papilla (u), spicule (e). Bar $=20 \mu \mathrm{m}$. 
and allotype: 38584b and paratypes: female 9c; paratypes: male 7d; paratypes: male $8 \mathrm{e}$; paratypes: male 10f; voucher female: $\mathrm{g}-\mathrm{h}$ ).

\section{Discussion}

The genus Cucullanus contains more 100 nominal species that parasitize freshwater, brackish, and marine fish (LÓPEZ-CABALLERO et al., 2009; YOOYEN et al., 2011; LACERDA et al., 2015). Moravec et al. (1993) was if the opinion that species of Cucullanus have a fairly uniform morphology and that some species had been described incorrectly; thus, performing a detailed comparison between all species was impracticable. Therefore, morphological and morphometric comparisons among different species should consider the taxonomic group of the host (MORAVEC et al., 2005; GONZÁLEZ-SOLÍS et al., 2007; LÓPEZ-CABALLERO et al., 2009; YOOYEN et al., 2011; PEREIRA et al., 2015) and the zoogeographical region in which the host was found (MORAVEC et al., 1997; SARDELLA et al., 1997; CASPETA-MANDUJANO et al., 2000; DANIEL et al., 2002; LANFRANCHI et al., 2004; CABAÑAS-CARRANZA \& CASPETA-MANDUJANO, 2007; PEREIRA et al., 2015; LACERDA et al., 2015) were selecting species for comparison.

In Brazil, genus Cucullanus contains 27 parasite species from 10 different orders of fish (Siluriformes, Perciformes, Cichliformes, Characiformes, Tetradontiformes, Gymnotiformes, Ophidiiformes, Anguilliformes, Lophiiformes, and Gadiformes) that are present in different aquatic environments, including freshwater, estuarine, and marine. The order Siluriformes contains the highest number of representatives of the genus Cucullanus. Cucullanus pinnai, C. zungaro, C. pauliceae (Syn. C. schubarti Travassos, 1947), C. oswaldocruzi, C. grandistomis, C. brevisciculus, C. pimelodellae, C. pinnai pterodorasi, C. pseudoplatystoma, C. heliomartinsi, and C. ageneiosus were described to parasitize Brazilian fish in three different aquatic environments. Cucullanus bagre described in Bagre bagre in Cayenne, French Guiana, and the North Atlantic Ocean was redescribed in Brazil by Pereira et al. (2015) in the same host in Angra dos Reys Bay, state of Rio de Janeiro, Brazil, South Atlantic Ocean.

Cucullanus marajoaran. sp. parasitizes C. psittacus (Tetradontiformes), which was collected in municipality of Soure, Marajó Archipelago, state Pará, but differs in habitat, biome, and host order from C. cirratus, C. pulcherrimus, C. carioca, C. rougetae, C. tucunarensis, C. protrudens, and C. pseudopercis, which are parasites of fish of the order Perciformes, which are mostly marine. C. tucunarensis and C. opisthoporus, parasites of freshwater fish of the genus Cichla (Cichliformes) in northern Brazil; differ morphologically from the new species because they present sclerotized spines at the tail end in the ventral region.

Hosts of the order Perciformes, which are mostly marine, include Cucullanus cirratus, C. pulcherrimus, C. carioca, C. rougetae, C. protrudens and C. pseudopercis followed by hosts of the order Tetradontiformes, including C. dodsworthi and C. brevicaudatus, and the orders Characiformes, Gymnotiformes, Ophidiiformes, Anguilliformes, and Lophiiformes, including C. mogi, C. rhamphichthydis, C. genypteri, C. pedroi, and C. gastrophysi, respectively.

Cucullanus dodsworthi and C. brevicaudatus are the only species described parasitizing fish of the order Tetradontiformes.
C. dodsworthi was originally described in Sphoeroides testudineus in Brazil (BARRETO, 1922). Campana-Rouget (1957) redescribed this species parasitizing Lagocephalus laevigatus in Senegal, Africa, and Mejía-Madrid \& Guillén-Hernández (2011) redescribed the species parasitizing Sphoeroides testudineus in Mexico. Cucullanus marajoara $\mathrm{n}$. sp. presents 10 pairs of cloacal papillae distributed in five ventral precloacal pairs, an unpaired papilla on the upper lip of the cloaca, and five postcloacal pairs (pairs No. 6, 8, and 10 are ventral, pair No. 7 is lateral, and pair No. 9 is dorsal); one pair of lateral phasmids located between pairs No. 8 and 10. C. dodsworthi also has ten pairs of papillae, but their distribution is unique [three ventral precloacal pairs, four adcloacal pairs, one unpaired precloacal papillae on anterior precloacal lip and three postcloacal pairs (two ventral pairs and one lateral pair)]. Moreover, Barreto (1922) and López-Caballero et al. (2009) did not observe protruded cloacal lips, which occur in the new species.

Cucullanus brevicaudatus, a parasite of $B$. capriscus (Tetraodontiformes: Balistidae), differs from the new species by the host family, habitat (marine), morphology of the gubernaculum well sclerotised, thin distally, enlarged and with small ornament proximally, tail size, and distribution of the caudal papillae (six pairs of precloacal papillae, one pair of adcloacal papillae, and three pairs of posterior papillae).

Cuculllanus marajoara n. sp. differs from other similar species that parasitize hosts of order Siluriformes by the host species and habitat, with the exceptions of C. oswaldocruzi, which is a parasite of the freshwater fish Paulicea luetkeni (Syn. Zungaro zungaro) found in the Curuá river, and $C$. ageneiosus, which is a parasite of the estuarine fish Ageneiosus ucayalensis; both of these species occur in Pará in the same zoogeographic region as the new species. Morphologically, Cucullanus marajoara n. sp. differs from these two species by the distribution of the cloacal papillae, including the presence of five precloacal pairs (the first pair is located anterior to the precloacal sucker, whereas pairs No. 2, 3, 4, and 5 are ventral and located posterior to the precloacal sucker) and five postcloacal pairs (pairs No. 6, 8, and 10 are ventral, pair No. 7 is lateral, and pair No. 9 is dorsal). The location of the phasmids between pairs No. 8 and 10 is a diagnostic feature of the new species and differs from $C$. ageneiosus, in which the phasmids are located immediately posterior to the tenth pair of papillae. In addition to belonging to a different host group, $C$. oswaldocruzi and $C$. ageneiosus do not present a protuberant cloacal upper lip and do not have an odd papilla on this lip, as has been observed in Cucullanus marajoara n. sp.

Cucullanus mogi (parasite of Characirfomes) and C. rhamphichthydis (parasite of Gymnotiformes) differ from the new species based on the host order and other morphological characteristics. Cucullanus mogi does not have a gubernaculum, whereas this structure is present in Cucullanus marajoara n. sp. (0.06-0.08 mm). Cucullanus rhamphichthydis parasitizes the freshwater fish Rhamphichthys rostratus in Paraná, Brazil, and only females have been used for the description of the species. The morphological characteristics that are important for the distinction of these species from the new species include the position of the nerve ring (0.354-0.476), deirids (1.63), excretory pore (1.81-2.30), and non-protruding vulval lips in females. Additional morphometric comparisons between Cucullanus marajoara n. sp. and the other species found in Brazil are presented in Table 1. 


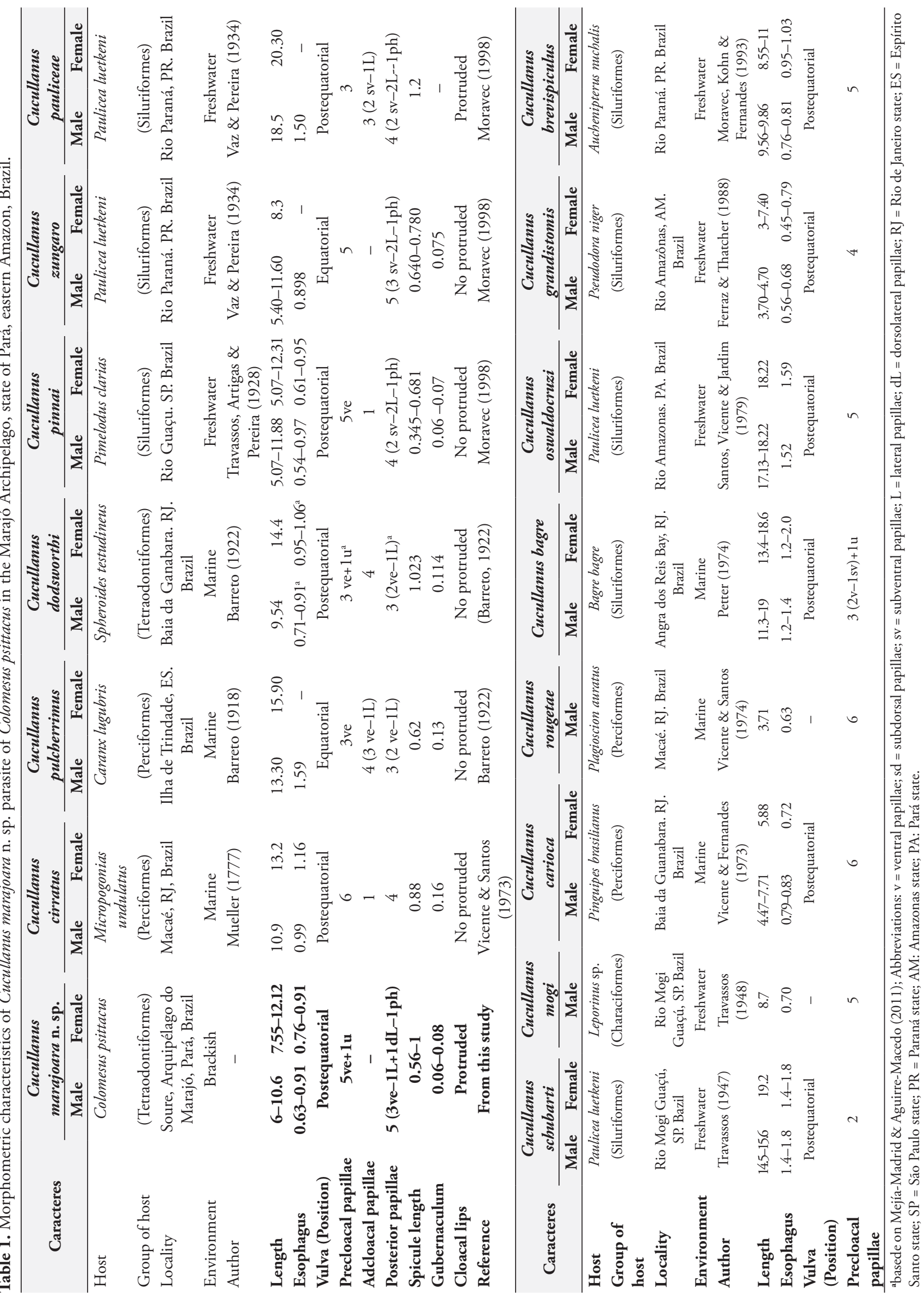




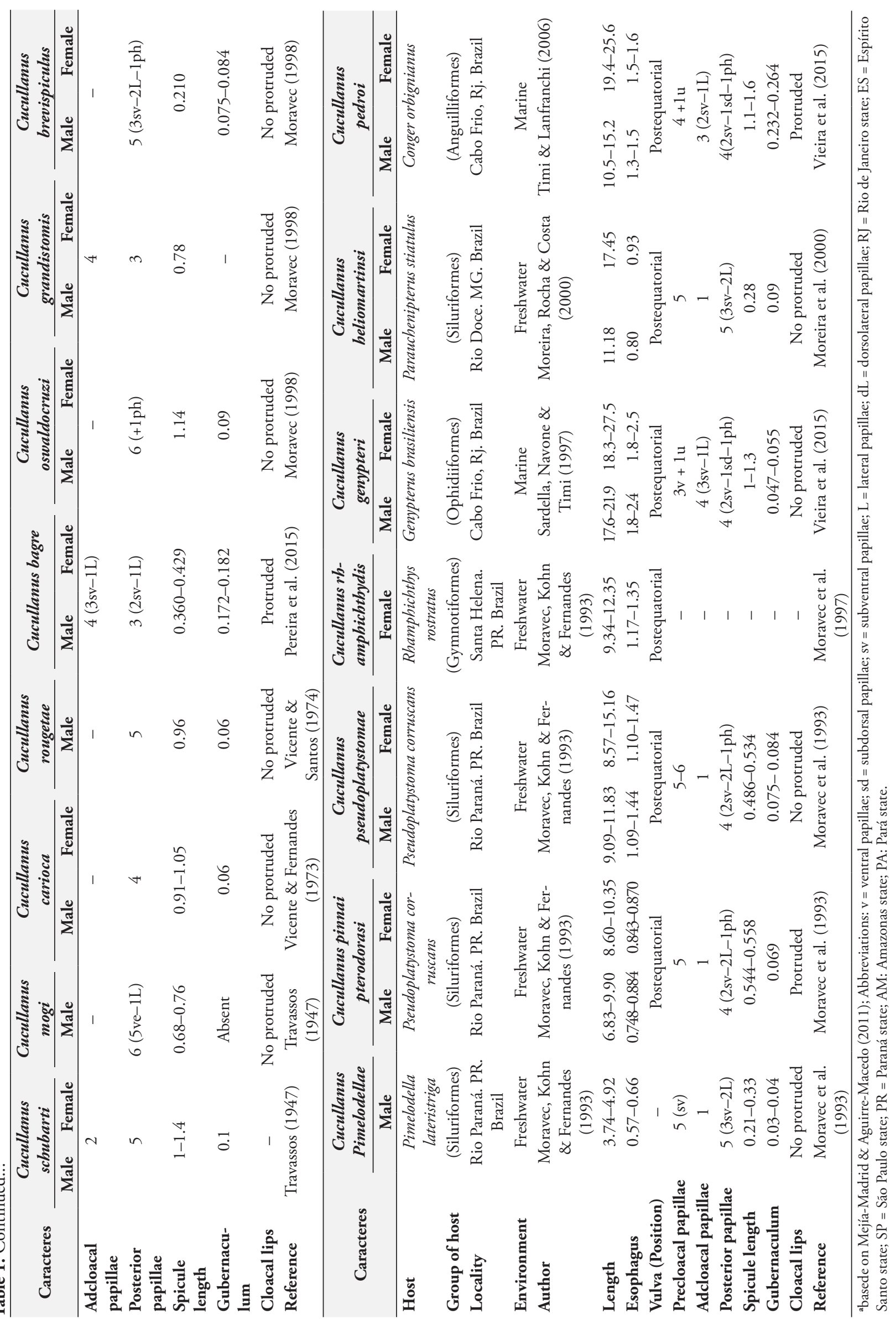




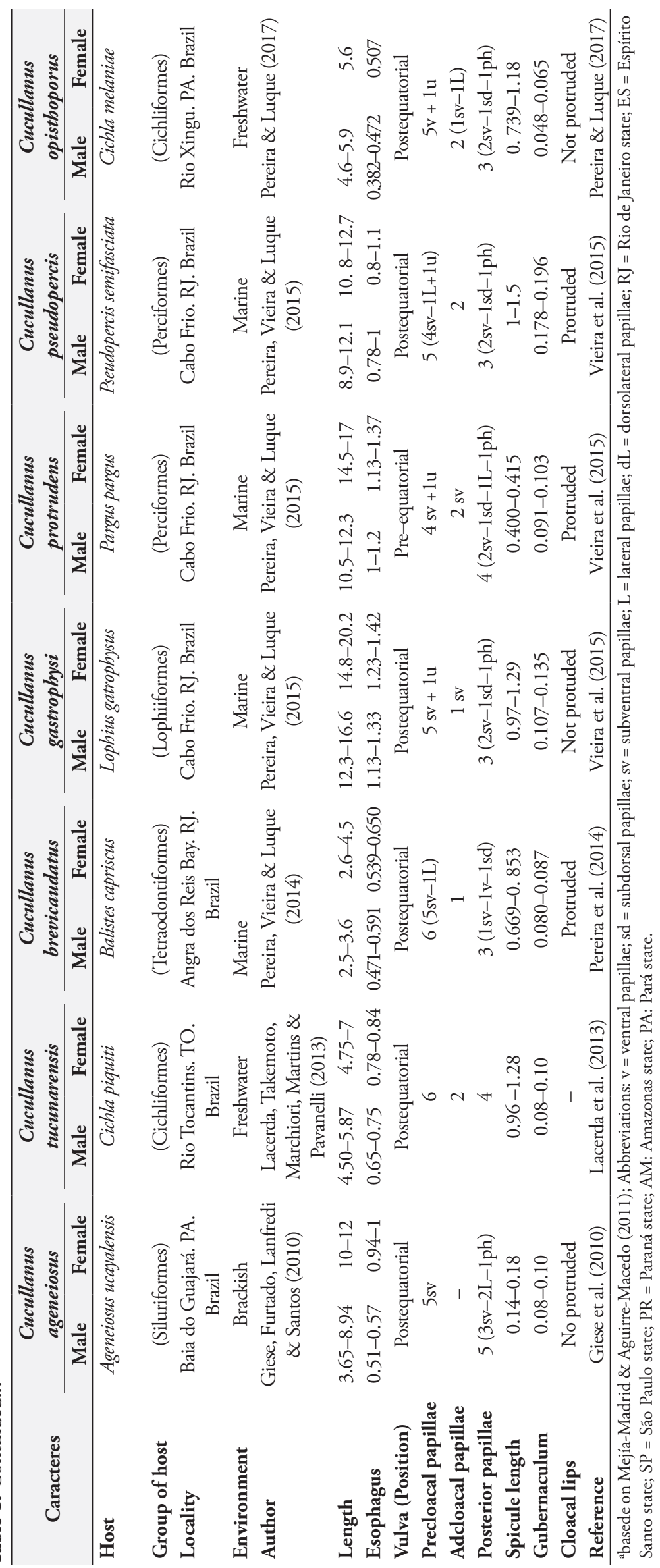


Vieira et al. (2015) studied marine fish and described C. gastrophysis, which is a parasite of Lophius gastrophysus (Lophiformes), and redescribed $C$. genypteri parasitizing Genypterus brasiliensis (Ophidiiformes), C. pedroi parasitizing Conger orbignianus (Anguilliformes), and C. cirratus parasitizing Urophycis brasiliensis (Gadiformes) in the states of Rio de Janeiro and Rio Grande do Sul. Cucullanus marajoara n. sp. differs from these species in the zoogeographical region, host order, and absence of adcloacal papilla, as observed in the four marine species C. gastrophysis (one pair, 1sv), C. genypteri (four pairs, 3sv-1L), C. pedroi (three pairs, 2 sv-1L), and C. cirratus (four pairs, 3sv-1L).

In conclusion, this study described Cucullanus marajoara n. sp. as the first species of the genus parasitizing C. psittacus in Marajó Archipelago region, in state of Pará, in eastern Amazon. This species is the second species of the genus living in estuarine environments in Brazil and adds new data to the diversity of fish parasites of the Tetraodontiformes in the Neotropical region.

\section{Acknowledgements}

The authors are grateful to the following the Laboratório de Histologia e Embriologia Animal and Laboratório de Microscópia Eletrônica de Varredura - Instituto da Saúde e Produção Animal - Universidade Federal Rural da Amazônia - UFRA, campus Belém, state of Pará, Brazil for the use of the scanning electron microscope. This study is part of the Ph.D. thesis of Raul Henrique da Silva Pinheiro, developed for the Programa de Pós-Graduação em Biologia de Agentes Infecciosos e Parasitários (Graduate Program in Biology of Infectious Agents and Parasites), Instituto de Ciências Biológicas (Biological Sciences Institute), Universidade Federal do Pará-UFPA. Financial support for this study was provided by the PAPQ2017/PROPESP/UFPA, Coordenação de Aperfeiçoamento de Pessoal de Nível Superior - CAPES and Ministério da Educação do Brasil.

\section{References}

Barreto AL. Notas helminthologicas III. Cucullanus pulcherrimus n. sp. de nematoideo. Bras Med 1918; 18: 137-138.

Barreto AL. Revision of the family Cucullanidae Barreto, 1916. Mem Inst Oswaldo Cruz 1922; 14(1): 68-87. http://dx.doi.org/10.1590/ S0074-02761922000100003.

Cabañas-Carranza G, Caspeta-Mandujano JM. A new cucullanid species (Nematoda) from the freshwater fish Vieja intermedia (Günther, 1862) (Cichlidae) in Mexico. J Parasitol 2007; 93(3): 646-649. http://dx.doi. org/10.1645/GE-987R.1. PMid:17626358.

Camargo M, Maia T. Análise populacional do baiacu, Colomesus psittacus (Tetraodontiformes, Tetraodontidae), no estuário o rio Caeté, costa norte do Brasil. Uakari 2008; 4(1): 23-28. http://dx.doi.org/10.31420/ uakari.v4i1.34.

Campana-Rouget Y. Parasites de poissons de mer ouest-africains récoltés par J. Cadenat. Nématodes. (4 note). Sur quelques espèces de Cucullanidae. Révision de la sous-famille. Bulletin IFAN 1957; 19(2): 417-473.

Caspeta-Mandujano JM, Moravec F, Aguilar-Aguilar R. Cucullanus mexicanus sp. n. (Nematoda: Cucullanidae) from the intestine of the freshwater catfish Rhamdia guatemalensis (Pimelodidae) in Mexico. Helminthologia 2000; 37(4): 215-217.

Cervigon F, Cipriani R, Fisher W, Garibaldi L, Hendrickx M, Lemus $\mathrm{AJ}$, et al. Guia de Campo de lãs espécies comerciales marinas y de águas salobres de la costa septentrional de Sur América. Roma: FAO; 1992.

Daniel VI, Timi JT, Sardella NH. Cucullanus marplatensis sp. nov. (Nematoda, Cucullanidae) parasitizing Odontesthes argentinensis (Valenciennes, 1835) (Pisces, Atherinidae) from Argentinean waters. Acta Parasitol 2002; 47(1): 41-46.

Froese R, Pauly D, editors. FishBase [online]. Mumbai: FishBase Team; 2018 [cited 2018 May 18]. Available from: www.fishbase.org

Giese EG, Furtado AP, Lanfredi RM, Santos JN. A New Cucullanid Species (Nematoda) from Ageneiosus ucayalensis Castelnau, 1855 (Pisces: Auchenipteridae) from Pará, Brazil. J Parasitol 2010; 96(2): 389-394. http://dx.doi.org/10.1645/GE-2081.1. PMid:19954256.

González-Solís D, Tuz-Paredes MV, Quintal-Loria MA. Cucullanus pargi n. sp. (Nematoda: Cucullanidae) from the grey snapper Lutjanus griseus off the southern coast of Quintana Roo, Mexico. Folia Parasitol (Praha) 2007; 54(3): 220-224. http://dx.doi.org/10.14411/fp.2007.030. PMid:19245194.

Krumme U, Saint-Paul U, Rosenthal H. Tidal and diel changes in the structure of a nekton assemblage in small intertidal mangrove creeks in northern Brazil. Aquat Living Resour 2004; 17(2): 215-229. http://dx.doi. org/10.1051/alr:2004019.

Lacerda ACF, Takemoto RM, Marchiori NC, Martins ML, Pavanelli GC. New species of Cucullanus (Nematoda: Cucullanidae), an intestinal parasite of the peacock bass Cichla piquiti (Perciformes: Cichlidae) from the Tocantins River, Brazil. J Helminthol 2015; 89(1): 9-12. http://dx.doi. org/10.1017/S0022149X13000485. PMid:23830176.

Lanfranchi AL, Timi JT, Sardella NH. Cucullanus bonaerensis n. sp. (Nematoda: Cucullanidae) parasitizing Urophycis brasiliensis (Pisces: Phycidae) from Argentinean waters. J Parasitol 2004; 90(4): 808-812. http://dx.doi.org/10.1645/GE-3276. PMid:15357074.

López-Caballero J, Osorio-Sarabia D, García-Prieto L. Cucullanus costaricensis n. sp. (Nematoda: Cucullanidae), a parasite of Bagre pinnimaculatus (Siluriformes: Ariidae) from Río Tempisque, Costa Rica. J Parasitol 2009; 95(2): 413-423. http://dx.doi.org/10.1645/GE-1682.1. PMid:18842070.

Luque JL, Aguiar JC, Vieira FM, Gibson DI, Santos CP. Checklist of Nematoda associated with the fishes of Brazil. Zootaxa 2011; 3082: 1-88.

Mejía-Madrid HH, Aguirre-Macedo ML. Redescription and genetic characterization of Cucullanus dodsworthi (Nematoda: Cucullanidae) from the checkered puffer Sphoeroides testudineus (Pisces: Tetraodontiformes). J Parasitol 2011; 97(4): 695-706. http://dx.doi.org/10.1645/GE-2664.1. PMid:21506838.

Mejía-Madrid HH, Guillén-Hernández S. A new cucullanid from the black grouper Mycteroperca bonaci (Osteichthyes: Serranidae) off the coast of Yucatán, México.J Parasitol 2011; 97(1): 122-127. http://dx.doi. org/10.1645/GE-2546.1. PMid:21348618.

Moravec F, Kohn A, Fernandes BMM. Nematode parasites of fishes of the Paraná River, Brazil. Part. 2. Seuratoidea, Ascaridoidea, Habronematoidea and Acuarioidea. Folia Parasitol (Praha) 1993; 40(2): 115-134.

Moravec F, Kohn A, Fernandes BMM. New observations on seuratoid nematodes parasitic in fishes of the Paraná River, Brazil. Folia Parasitol (Praha) 1997; 44(3): 209-223. PMid:9332979. 
Moravec F, Sasal P, Wurtz J, Taraschewski H. Cucullanus oceaniensis sp. n. (Nematoda: Cucullanidae) from Pacific eels (Anguilla spp.). Folia Parasitol (Praha) 2005; 52(4): 343-348. http://dx.doi.org/10.14411/ fp.2005.047. PMid:16405298.

Moravec F. Nematodes of freshwater fishes of the Neotropical region. Prague: Academia; 1998.

Moreira NIB, Rocha GN, Costa HMA. A new nematode species (Seuratoidea, Cucullanidae) parasitizing Parauchenipterus striatulus (Steindachner, 1876) (Pisces, Auchenipteridae) in Brazil. Mem Inst Oswaldo Cruz 2000; 95(1): 39-41. http://dx.doi.org/10.1590/S007402762000000100005 . PMid:10656702.

Pereira FB, Luque JL. Morphological and molecular characterization of cucullanid nematodes including Cucullanus opisthoporus n. sp. in freshwater fish from the Brazilian Amazon. J Helminthol 2017; 91(6): 739-751. http://dx.doi.org/10.1017/S0022149X16000729. PMid:27776573.

Pereira FB, Vieira FM, Luque JL. A new species of Cucullanus Müller, 1777 (Nematoda: Cucullanidae) parasitic in the grey triggerfish Balistes capriscus Gemlin (Osteichthyes: Balistidae) off Rio de Janeiro, Brazil. Syst Parasitol 2014; 87(3): 283-291. http://dx.doi.org/10.1007/s11230-0149470-y. PMid:24563144.

Pereira FB, Vieira FM, Luque JL. New morphological data and first description of gravid female of Cucullanus bagre Petter, 1974 (Seuratoidea: Cucullanidae) from Bagre bagre (Linnaeus, 1766) (Siluriformes: Ariidae) off Brazil. Acta Parasitol 2015; 60(1): 138-145. https://doi.org/10.1515/ ap-2015-0019. PMid:26204032.

Petter AJ. Deux nouvelles spèces de Cucullanidae parasites de poissons en Guyane. Bulletin du Museum National d'Histoire Naturelle de Paris, $3^{a}$ série, $n^{\circ} 255$. Zoologie 1974; 177: 1459-1467.

Santana PL No, Aquino EC, Silva JA, Amorim ML, Oliveira AE Jr, Haddad V Jr. Fatal poisoning caused by puffer fish (Tetrodontidae): report of a case involving a child. Rev Soc Bras Med Trop 2010; 43(1): 92-94. PMid:20305977.
Sardella NH, Navone GT, Timi JT. A new species of Cucullanus (Nematoda: Cucullanidae) parasite of Genypterus blacodes and G. brasiliensis (Pisces: Ophidiidae) in the south West Atlantic. Parasite 1997; 4(1): 41-47. http://dx.doi.org/10.1051/parasite/1997041041.

Timi JT, Lanfranchi AL, Tavares LER, Luque JL. A new species of Dichelyne (Nematoda, Cucullanidae) parasitizing sciaenid fishes from off the South American Atlantic coast. Acta Parasitol 2009; 54(1): 45-52. http://dx.doi.org/10.2478/s11686-009-0010-x.

Timi JT, Lanfranchi AL. A new species of Cucullanus (Nematoda: Cucullanidae) parasitizing Conger orbignianus (Pisces: Congridae) from Argentinean waters. J Parasitol 2006; 92(1): 151-154. http://dx.doi. org/10.1645/GE-3513.1. PMid:16629329.

Vicente JJ, Fernandes BMM. Sobre um novo nematódeo do gênero Cucullanus Mueller, 1777, parasito de "namorado" (Nematoda, Camallanoidea). Atas Soc Biol Rio de 1973; 17(1): 31-33.

Vicente JJ, Santos E. Alguns helmintos de peixe do litoral norte fluminense. Mem Inst Oswaldo Cruz 1973; 71(1-2): 95-113. http://dx.doi.org/10.1590/ S0074-02761973000100006.

Vicente JJ, Santos E. Alguns helmintos de peixes do litoral norte fluminense - II. Mem Inst Oswaldo Cruz 1974; 72(3-4): 173-180. http:// dx.doi.org/10.1590/S0074-02761974000200002.

Vieira FM, Pereira FB, Pantoja C, Soares IA, Pereira AN, Timi JT, et al. A suvey of nematodes of the genus Cucullanus Müller, 1777 (Nematoda, Seuratoidea) parasitic in marine fish off Brazil, incluiding description of three new species. Zootaxa 2015; 4039(2): 289-311. http://dx.doi. org/10.11646/zootaxa.4039.2.5. PMid:26624480.

Yooyen T, Moravec F, Wongsawad C. Two new species of Cucullanus Müller, 1777 (Nematoda: Cucullanidae) from marine fishes off Thailand. Syst Parasitol 2011; 78(2): 139-149. http://dx.doi.org/10.1007/s11230010-9286-3. PMid:21279563. 